\title{
Brains and psyches: Child psychological and psychiatric expertise in a Swedish newspaper, 1980-2008
}

Peter Skagius

The self-archived postprint version of this journal article is available at Linköping University Institutional Repository (DiVA):

http://urn.kb.se/resolve?urn=urn:nbn:se:liu:diva-1593.57

N.B.: When citing this work, cite the original publication.

Skagius, P., (2019), Brains and psyches: Child psychological and psychiatric expertise in a Swedish newspaper, 1980-2008, History of the Human Sciences, (3), 76-99.

https://doi.org/10.1177/0952695118810284

Original publication available at:

https://doi.org/10.1177/0952695118810284

Copyright: SAGE Publications (UK and US)

http://www.uk.sagepub.com/home.nav 


\section{Introduction}

During the $20^{\text {th }}$ century, childhood in the West experienced increasing demarcation and intervention from professionals and experts such as psychologists and psychiatrists. They have defined the 'normal' child, offered explanations for children's mental health and contributed to the expanding institutionalization of children's everyday lives (Rose, 1999; Börjesson and Palmblad, 2003; Sandin and Halldén, 2003). Children's lives have thus been shaped and organized by experts' knowledge and practices. But while some children and parents have directly interacted with child psychological and psychiatric experts, many have not. Instead, newspapers, magazines, radio and television have been important avenues for disseminating psychological and psychiatric notions of, for instance, childhood disorders and risks, good parenthood, and therapeutic methods (Börjesson, 1999; Clarke, 2011; Jones, 2012; Shapira, 2013, 2017). Analyses of media material are thus crucial for the history of psychology and psychiatry as the media has been one of the historically significant ways through which experts and professionals have been able to present their understandings and explanations to the general public and speak to those who are otherwise out of reach.

In this article, I set out to analyze how child 'psy experts' (Rose, 1996, p. 13) have discussed children's mental health in Sweden's largest morning paper Dagens Nyheter. Drawing on Actor-Network Theory, I conceptualize the various strands of the child psy sciences as different 'modes of ordering' (Law, 1994) that, through assembling varying sets of psychological, biological and social entities, theoretical understandings and explanatory frameworks, produce specific, historically situated versions of children's mental health. In the analysis, I focus on two modes of ordering that were prominent in the paper during significantly overlapping periods: a psychodynamic mode (1980s-1990s), and a neurocentered mode (1980s-2008). While the material precludes me from drawing any conclusions regarding 
how readers actually understood or potentially adopted these modes, it does indicate which child psy modes were circulating at a particular time and could have been encountered by the public (Gleason, 1996).

The two modes of ordering are particularly interesting to consider because, although quite contemporaneous, they offered starkly different conceptions of children's mental health. Each mode revolved around a central entity - the unconscious and the brain, respectively - and related this to a host of social contexts, material entities, developmental notions and psychological and psychiatric knowledges that together came to form that mode's enactment of children's psychological health.

The psychodynamic mode, which encompassed theories developed by psychoanalysts such as Donald Winnicott and Margaret Mahler, consistently emphasized how the child's relation with its parents was vital for the former's mental health. As the child's psyche was constituted by internalizing the parents' actions and feelings, they had to be attuned to the child's needs and willing to demonstrate unconditional love. The neuro-centered mode, in contrast, encompassed a more heterogeneous set of entities, particularly as it entailed two versions of 'the brain.' The 'normal' brain version stressed that parents had to cognitively and affectively stimulate the child to promote the beneficial development of its plastic brain. The 'atypical' brain version was instead described as quite static, unresponsive to outside influences and frequently related to diagnoses such as ADHD (Attention Deficit Hyperactivity Disorder) or Autism. This kind of child primarily needed behavioral interventions alongside support and understanding from society. The two modes therefore had very distinct implications for the Swedish public for how to understand and order children's mental health.

This article contributes on both empirical and theoretical levels. First, its results shed light on a hitherto relatively unexplored part of the history of the psy sciences in Sweden by analyzing media 
material published in a Swedish context during the latter part of the $20^{\text {th }}$ century. This opens up space for comparisons and contrasts with international studies on the history of the child psy sciences (e.g. Shapira, 2013) as well as with the few Swedish studies that have covered similar years but mainly analyzed other kinds of material (e.g. Zetterqvist Nelson and Sandin, 2013). Furthermore, while some of the findings concur with previous studies - for instance, the psychodynamic mode's emphasis on parents as the cause of ill-health (cf. Vicedo, 2011) - the results suggest alternative ways of understanding the psy sciences and their social implications. For example, the neuro-centered mode did not entail a strong pharmacological medicalization of children, in contrast to what some have argued (cf. Timimi, 2010), and instead often stressed the social context of these problems and disorders. The analysis thus shows that the psy sciences are multifaceted, with complex implications and uses (Wright, 2008).

Second, the article makes a theoretical and methodological contribution, primarily by drawing on Actor-Network Theory, a hitherto quite uncommon analytical framework in the history of the psy sciences (however, for some examples see Ward, 1996; Bommenel, 2006; Skagius and Münger, 2016). I am thus engaging with Volker Hess and Benoît Majerus' (2011, p. 141) encouragement to explore forms of historical scholarship that do not primarily draw on the 'antipsychiatric habitus and criticism' underlying many of the commonly used historical approaches. In these studies (e.g. Clarke, 2013), society and the social context are often givens which are used to explain the sciences, instead of being entities and categories that are themselves modified in and through scientific work (Ward, 2002). Such analytical approaches may thereby forego analyzing important aspects of these sciences and their implications. In this article, I show how Actor-Network Theory is a fruitful alternative that can address such shortcomings. 
I start by reviewing the history of the Swedish child psy sciences in order to give some background to my material and analytical discussions. I then describe my theoretical and methodological framework and argue for the relevance of Actor-Network Theory in historical studies of the psy sciences. This is followed by an analysis of the two modes, after which I conclude with a more general comparison between the discussed modes, clarify what was at stake in each mode, and briefly discuss my ActorNetwork Theory narrative in relation to other forms of historical narratives.

\section{The history of the Swedish child psy sciences}

Studies of the early years of Swedish child psychology and psychiatry (Qvarsell, 1985, 1993; Zetterqvist Nelson, 2016) have shown that the establishment of these disciplines during the first decades of the $20^{\text {th }}$ century was closely related to social issues, such as concerns about rising child and youth delinquency. While such fears were not new, these issues were now increasingly couched in medical and pedagogical terms; for instance, the popular 'child psychopathology' concept (Axelsson, 2009), designating children of normal intelligence but with emotional, behavioral and/or volitional problems. Child psychology and psychiatry were thus posited as important, scientific means to counter social problems. There were prominent hereditary and biological models of thought during these decades that argued for internment, contraceptives and, particularly during the interwar period, sterilization (Qvarsell, 1991), but they had little actual impact on the nascent Swedish child psychiatry. Instead, it was the preventive and pedagogical conceptions of the mental hygiene movement, which fit well with the political views of many Swedish reformists and politicians, that were most influential in shaping the early child psychiatric institutions (Jönson, 1997).

The shifts during the 1920 s and '30s in the conceptualization of children's mental health did not, however, correspond with similar changes in therapeutic methods as they still mostly entailed an 
educative approach that combined psychology, pedagogy and medicine (Qvarsell, 1993). Yet, there were exceptions to be found during this period, such as the privately organized Erica Foundation, which drew significantly on child psychoanalytical theories (Bergenheim, 2013) and over time came to develop influential therapeutic techniques, such as a psychoanalytically modified version of Margaret Lowenfeld's Sandtray method (Zetterqvist Nelson, 2011).

It was not until after World War II that formalized therapeutic methods became more prominent, as shown by Karin Zetterqvist Nelson and Bengt Sandin (2013) in their historical study of Swedish governmental reports and policy documents on the child psychiatric services. The reports published in the late 1940 s and '50s combined a psychoanalytical emphasis on the 'deeper' emotional aspects of the child, with an interventionist political vision in which child psychiatry was given a proactive role in improving children and young people's living conditions. Nevertheless, the treatments actually offered seem to have been quite diverse and also included traditional child psychiatric methods. However, during the mid-1960s, the reports claimed, child psychoanalytic approaches became the norm in practice as well, a change that coincided with an intense expansion in the number of child psychiatric clinics and professionals (Zetterqvist Nelson and Sandin, 2013).

At this point, we should briefly discuss Swedish research on the history of attachment theory as its reception by Swedish postwar child psychiatry and psychology differed from that of their Anglo-Saxon counterparts (for more on the latter, see Vicedo, 2013). Attachment theory was familiar to at least some Swedish child psychologists and psychiatrists in the early 1950s and Bowlby even visited Sweden in 1950 as part of his WHO-funded project (Zetterqvist Nelson, 2017a). Yet the theory never achieved any real purchase among Swedish psy experts. Zetterqvist Nelson (2009) argues that this may have been because Bowlby's theory built on the notion that the mother was the only appropriate caregiver for the child. 
Many Swedish child experts considered this to be too narrow a conceptualization which underestimated the quality of Swedish child institutions. The theory's implications also went against the political view held by many Swedes that collective childcare was valuable and that fathers had an important role in child rearing. Attachment theory's views on children's mental health were thus seen as inapplicable to Swedish circumstances and it was not until the 1980s that the theory started to make headway in Sweden.

During the late 1960s and early '70s, Swedish adult psychiatry was heavily criticized and politicized (Ohlsson, 2008), but child psychiatry escaped such fervent criticism (Zetterqvist Nelson and Sandin, 2013). There was, however, a strong interest in socially and politically oriented family therapy, best represented by Barnbyn Skå (Child village Skå). Barnbyn Skå was then an institute organized around treating families in a collective, egalitarian community where they lived alongside the staff (Bergenheim, 1997). Eschewing any biological views on mental illness, Barnbyn Skå instead stressed the therapeutic importance of attending to social and political factors. The institute had previously been strongly criticized for its perceived laxness with children and its therapeutic emphasis on children's sexuality, but during the late 1960s it was praised by many as a role model for how to treat children.

The interest in social and political therapies started to wane during the late 1970s and early '80s, partly, as argued by Ohlsson (2008), due to a less intense politicization in the public debate on psychiatric and psychological issues and a waning political Left that could no longer dictate the framing of political and social topics. In their place, a more traditional psychodynamic and psychoanalytical perspective became predominant once more (Rigné, 2002; Zetterqvist Nelson and Sandin, 2013), but now with an important twist. No longer was the social and political potential of psychoanalytical theory 
foregrounded; instead, individualized treatment, with a basis in American ego psychology, was stressed, turning the focus toward the inner life of children without any explicit connections to politics or society.

There are just a few historical studies that directly engage with the child psy sciences in Sweden from the late 1980s onward. They primarily either focus on earlier decades and merely include short glimpses of the 1990s and 2000s (e.g. Bergenheim, 2013) or explore other topics and only secondarily touch on child psychology and psychiatry (e.g. Littmarck, 2017). While these studies do show that child psy expertise seems to have played an important role in various Swedish contexts during these decades, the lack of an explicit focus on the child psy sciences means that they only paint a partial picture of what these forms of expertise imply for conceptualizations of children's mental health.

This article addresses this gap in the literature by analyzing how child "psy experts" in the Swedish morning paper Dagens Nyheter discussed children's mental health from the 1980s up until 2008. It thus contributes to the literature both by focusing on this relatively unexplored period and by examining an important kind of material that can shed light on the forms of child psy expertise that the Swedish public was likely to encounter during these decades.

\section{Theoretical orderings}

In this article, I draw on Actor-Network Theory (hereafter abbreviated to ANT) to conceptualize and analyze the forms of child psy expertise in my material. ANT argues that no entity or phenomenon - be it an illness, a body, the law or 'Nature' - is to be seen as an already formed substance. Rather, it is an effect produced by and enacted through materially heterogeneous assemblages that often encompass both words and things, humans and nonhumans (Latour, 1996; Mol, 1999; Law, 2008a). 
These assemblages, following John Law (1994), can be termed 'modes of ordering,' designating messy, fragile yet relatively coherent patterns of ordering that through associating, inter alia, objects, contexts, notions, instruments and humans, sometimes and in some places generate precarious 'pools of order' (1994, p. 15). The partiality and uncertainty of such modes means that it is often possible to discern many contemporaneous ordering modes that interact in complex ways: partly overlapping, partly clashing or simply co-existing in isolation (Mol, 2002; Law et al., 2014). In this article, I approach the historically varying ways in which the experts and professionals in my material enacted children's mental health as representing different modes of ordering. Each mode related children's mental health to a particular set of human and nonhuman entities, with distinct consequences for how the mental illhealth of children was conceptualized.

ANT, with its concept of modes of ordering, was chosen as my analytical framework for several reasons. First, its stress on the material heterogeneity of modes made me aware of how they could potentially order more than solely human actors, such as children, parents or professionals. Indeed, relations to nonhumans, for instance social institutions and biological processes, were significant for distinguishing each mode's enactment of the mental health of children. To assume that humans would constitute the most important actors within these modes would thus have obscured important distinctions between them.

Second, the openness to complex and noncoherent relations between modes that ANT's 'littlenarrative, thoroughly empirically-grounded, very material, small-scale' (Law, 2008b, p. 632) analyses allow for may be particularly relevant to the history of the psy sciences as it has been characterized by a multiplicity of viewpoints, ontologies and practices (Ash, 2003; Teo, 2005; Scull, 2015). Nevertheless, this conflictual history does not preclude them from still sharing certain similarities which, I would 
argue, are more easily distinguishable using ANT's ontologically agnostic and empirically focused approach.

Third, I contend that ANT holds some promise for studying the history of the psy sciences by offering a slightly alternative framework which in particular differs on the question of contextualization. Contextualization has been described as 'a golden rule of historical inquiry' (Shogimen, 2016, p. 235) whereas ANT has been characterized as 'an anticontextualizing approach' (Asdal, 2012, p. 383) that has questioned whether scientific practices and theories can be explained by or seen as a reflection or expression of an underlying - or overarching - social context or structure (Latour, 1999, 2005).

One concern has been that such strong contextualizations tend to occlude the ontological productivity and novelty of the sciences by positioning the new entities that they articulate and materialize into an already given ontology, supplied by the analytical framework. ANT has rather aimed to create a space where actors and entities can 'do something in and to the world which cannot be traced back to that which was already there' (Asdal, 2012, pp. 397-398; italics in original). ANT scholars have tried to do this by problematizing and experimenting with the uses of contextualization (e.g. Callon, 1986; Ward, 2002; Law and Moser, 2012; Asdal, 2015), primarily to move away from the notion of a given analytical - and often human - context surrounding the study object. The emphasis has instead been on considering how actors - both human and nonhuman - enact their own contexts and make these relevant in their practices.

In this article, I have grappled with this issue by closely following the experts' and professionals' enactments of children's mental health while still using previous research to discuss similarities between and differences from other national contexts and historical periods. Concretely, this means that I have approached the discussions featured in the paper as statements that enact particular versions of 
children's mental health, without seeing them as determined by, or an expression of, their social context. Following Rita Felski (2011, p. 585), I have assumed that 'the significance of a text is not exhausted by what it reveals or conceals about the social conditions that surround it. Rather, it is also a matter of what it makes possible in the viewer or reader.' This, I argue, also includes highlighting the social and material context that each mode itself enacted as important in relation to children's mental health (see the concluding discussion for more on this point). So, while the modes discussed in this article undoubtedly draw on historical, social and intellectual entities recognizable from other periods and contexts, they also reconfigure these by embedding them in new relational assemblages, with novel effects. I have strived to balance these two aspects in order to discuss the historical lineages of each mode without losing their specificity.

Finally, ANT addresses some of the criticism that has been levelled toward certain tendencies and features of the field's commonly used analytical approaches, including that these often start from notions of society that are too static (Ward, 2002), use concepts such as medicalization in an overly coarse manner (Rose, 2007) and overemphasize the regulatory and controlling aspects of the psy sciences (Thomson, 2006; Wright, 2008). There is thus much to gain by exploring theories and methods that are grounded in alternative ontological, epistemological and critical frameworks (see Felski, 2015, for a more general discussion of the relation between critique and the social sciences and humanities). ANT, with its detailed empirical focus, ontological openness and experimental take on contextualization, can therefore constitute an important methodological addition to the history of the psy sciences.

\section{Material and analytical procedure}

The empirical material consists of articles published in Dagens Nyheter (Today's News; abbreviated DN). For many decades, it has been Sweden's largest morning paper and today has around 300000 
subscribers (Peter Wolodarski, 2017) and a total daily readership of ca 625000 (Dagens Nyheter, 2018). DN describes itself as politically independent but with a liberal stance (Dagens Nyheter, 2008) and has been characterized as Sweden's opinion-leading newspaper influencing other Swedish media actors (Olofsson, 2002). DN therefore provides particularly interesting material to examine since not only does it reach quite a large proportion of Swedes every day, but it also strongly influences what the Swedish media in general chooses to report.

While this article is part of a larger project studying the history of the child psy sciences from 1968 to 2008 , in this article I focus solely on the years 1980 to 2008 . I chose to end in 2008 because a period of almost three decades allowed me to trace possible shifts in the experts' discussions over an extended period of time while also covering many of the years that have not previously been extensively studied. To keep the amount of material manageable, I limited myself to examining a four-week period (from August $16^{\text {th }}$ to September $20^{\text {th }}$ ) every second year from 1980 to 2008 (e.g. 1980, 1982, 1984, ...). I chose this set of weeks as there are often many articles featuring children and young people during the start of the new school year (Söderlind and Engwall, 2005). A possible drawback of this approach is that I miss articles discussing child psychology and psychiatry published during either the rest of the year or during the odd years. Yet, the examined sets of weeks should be close enough to each other to reveal any major shifts in the discussions despite possibly missing the occasional article. It should be noted that the format of DN changed somewhat over the years and the paper's sections were renamed several times. This is why in some years I refer to, for example, DN B and at other times to DN Kultur, despite them being comparable in terms of content.

As a first step, each issue was examined and any content mentioning children's mental health and development, or psychology and psychiatry in general, was saved. I subsequently established an index 
organized by the year and date when the articles were published, resulting in 351 items. These were then read in detail, resulting in a more fine-grained selection of 131 articles that directly discussed children's mental (ill-)health and/or psychological development.

The main content of each article was then summarized in a separate document along with quotes that illustrated how children's mental health was enacted in the article. Following ANT's relational orientation, I traced how in each article the mental health of children was associated with, for instance, parents, biological functions, psychological notions and/or social institutions. In this way, I mapped how each article embedded children's mental health in a particular assemblage. After every relevant article had been mapped, I analyzed which articles encompassed similar relational enactments, i.e. related children's mental health to similar categories, entities, theories or explanations. The articles that enacted the mental health of children in a very similar way were then considered to be part of the same ordering mode, each of which was named based on what I perceived to be central to the mode.

As noted above, in this article I will discuss a psychodynamic and neuro-centered mode of ordering children's mental health. There were other modes of ordering discernable during the examined decades. For instance, a mode with a basis in attachment theory started to emerge during the mid2000s. However, I chose to focus specifically on the psychodynamic and the neuro-centered modes as they were quite contemporaneous with each other over several years yet represented contrasting modes of ordering children's mental health, with significant consequences for how readers, including parents, were supposed to understand and manage children's psychological health. So, while my selection unavoidably entails a certain simplification that does not do justice to the breadth of the material or to the complex relations between the various historical modes of ordering children's mental health, this, I argue, is offset by an increase in analytical intelligibility and depth. 
Two broad questions have guided the analysis. First, how did the psychological and psychiatric professionals and experts associated with the psychodynamic and the neuro-centered modes discuss children's mental health, and what human and nonhuman entities figured in their discussions and explanations? Second, what consequences and implications did these two ways of ordering children's mental health have for how to understand, prevent and/or alleviate children's psychological problems and disorders?

\section{Two modes of ordering}

\section{A psychodynamic mode of ordering}

Studies have shown that psychodynamic theory was quite influential in Sweden during the 1980s, both on a political level (Zetterqvist Nelson and Sandin, 2013) and among psy professionals such as psychologists, where it remained very predominant until the late 1990s (Rigné, 2002; Skagius and Münger, 2016). It was also prominent in DN during these decades ${ }^{1}$ as experts and professionals repeatedly informed readers that children's mental health was related to the child's unconscious.

Before continuing with the analysis, I first want to specify which psychodynamic traditions this mode encompassed, as psychodynamic theory is a vast and diverse body of thought (Mitchell and Black, 1995). The mode of relevance here mainly drew on American Ego psychology and British object relations theory, with their respective emphases on the adaptation to external reality and the process of internalization. But while articles could differ, due to their theoretical underpinnings, on what they specifically emphasized, they all stressed how the child's early relations were fundamental for structuring its psyche. 
Although the child's unconscious was posited as vital to consider in this mode, the enactments of the child and its psyche in the articles were quite ambivalent, oscillating between performing the child's inner world as solely a product of its relationships and as consisting of an authentic core that, in some sense, preceded these relationships. The former version can be exemplified by a quote from Joyce McDougall, a psychoanalyst who trained under Anna Freud and Jacques Lacan and wrote several books on psychoanalytical theory and practice (e.g. McDougall, 1985). She explained in an interview in 1988 that every human contains 'a universe of thoughts, feelings and dramas and a number of characters parts of ourselves and various images of people who have mattered to us' (DN, 1988, 17 September, p. 42). These hidden unconscious actors, she continued, often fight against each other, leading to psychological suffering and conflicts. Her metaphor illustrates how the psychodynamic mode partly enacted the child's inner life as formable from birth by being constituted relationally through the child's experiences with caretakers and significant others, making it into a form of container that was gradually filled with and structured by internalized interactions and affects.

The mode's other version of the child presupposed that there was within the child an authentic kernel that the parents - and especially the mother - had to perceive and attune to by unconditionally accepting and loving the child. This is exemplified by the doctor and psychoanalyst Clarence Crafoord who, in an article published in 1986, used Margaret Mahler's theory on the child's separationindividuation process to explain the mother's significance for preventing 'borderline disorder'. Crafoord noted that the child 'does not develop in a vacuum but in a continuously on-going dialogue with the surroundings .... This dialogue, this emotional accompaniment between mother and child ... is as important for human life as the air that we breathe' (DN, 1986, 4 September, p. 42). Crafoord also argued that 'the for the child most important meaning of the dialogue with the mother is that it [sic] feels that it may exist in its own right.' The pathological mother was, in contrast, too preoccupied with 
her own fictional image of the child, causing the actually existing child to slowly wither away psychologically. Similar warnings were given in several other articles during the late 1980s and early '90s (e.g. DN, 1988, 20 September, p. 45; DN C, 1990, 19 August, p. 6), underscoring the danger of parents prioritizing their own needs and desires, and thus forcing the child to repress their feelings in order to appease the parents.

This appeal to an inner authenticity can also be seen in articles detailing how psychological problems and disorders were a product of the child's attempts to survive in a destructive relationship. Referencing Donald Winnicott's theories, one essayist argued that disorders such as psychoses and autism were actually a fear of 'a primordial torment' that with time had led to 'a defensive organization that the patient makes known in the form of an illness syndrome.' Such an individual would rather choose 'sickness and death than the pain of abandonment, followed by hate and feelings of revenge' (DN B, 1992, 23 August, p. 16). Psychological disorders were thus historical, interpersonal childhood traumas that the child had tried to survive and overcome by developing specific patterns of relating and feeling, leading them to repress important parts of their inner self - an act which in many cases would come to haunt the future adult.

There was thus clearly a tension in the psychodynamic mode between, on the one hand, figuring the child's inner world as something created psychologically through the parents' care-taking and, on the other, as an inner kernel of authenticity that had to be perceived, acknowledged and respected. There are both overlaps and dissimilarities to be found between these enactments of the child and certain earlier child psychoanalytical notions, such as those prominent in Britain during World War II (Shapira, 2013). While these also emphasized the importance of the child's relations with the parents, they drew on child psychoanalysts such as Melanie Klein to argue that the child's psyche was filled with 
aggressiveness and anxiety that the parents had to harbor and tolerate. In contrast, the prominent theories and explanations of the psychodynamic mode led to rendering the child's inner world less 'threatening' as it was either empty and waiting to be structured by the parents or encompassed an authentic, benevolent essence. The mode thus retained certain older psychoanalytical emphases while integrating them with newer psychoanalytical understandings and explanations.

The two versions of the child were, moreover, related to distinct explanations of what caused mental ill-health. In one version, it was the internalization of negative parental images while, in the other, it was the repression of the child's authentic self. Nevertheless, they both underlined how the child's mental health was to a large degree dependent on the parents - and nothing else. A role for the parents was thus carved out that burdened them with responsibilities for the child's future health, similar to the findings of previous studies on the history of psychodynamic and psychoanalytical theory (e.g. Vicedo, 2011).

The psychodynamic mode's ordering also related the issue of mental health to a particular way of enacting the boundary between childhood and adulthood. First, the mode entailed a constant uncertainty about whether reality was perceived objectively by a person, as early life experiences could act as a filter that distorted the perception of reality to bring it into line with one's expectations from childhood (DN, 1984, 6 September, p. 40). Some unresolved childhood conflicts could even make adults act these out in real-life situations, as described in an article from the early 1990s that related how one psychotherapy client had 'incorporated all the father's dark aspects into himself' and become 'stuck in a negative father complex' in which he saw 'a destructive father in all authorities he meets and "happens" to get embroiled in conflict with them' (DN B, 1992, 30 August, p. 16). As illustrated here, the psychodynamic ordering mode entailed a diffuse boundary between child and adult, both 
psychologically and agentically. Childhood and adulthood were in this manner not enacted as two distinct states separated in time but as end points on a spectrum between which the individual could shift psychologically depending on whether the situation evoked their childhood experiences.

A second, but closely related, aspect is that the mode performed time as non-linear. Just as individuals could move between childhood and adulthood, they could also move psychologically between being in the past or the present. As two psychologists-in-training, featured in an interview in 1990 about their graduate thesis on female leadership in the workplace, cautioned: the man whose manliness was threatened could suddenly experience 'the mother from whom he has separated earlier.' The woman's competition with the female boss could likewise remind her of 'the oedipal situation where the girl competes with the mother for the father's favors' (DN B, 1990, 22 August, p. 16). Time was thus made bi-directional, blurring past and present. In this manner, the psychodynamic mode made it possible to transform any situation or issue into fundamentally being about a person's childhood experiences. Childhood was not enacted as simply a stage to grow out of and leave behind; it was an ever-present chaotic undercurrent, even into adulthood. Yet the articles stressed that there were ways to remedy this temporal and developmental entanglement, particularly by seeing a psychodynamic therapist to work through and fully understand one's childhood (e.g. DN B, 1990, 25 August, p. 1; DN B, 1992, 23 August, p. 16).

The psychodynamic mode's dimensional framing of childhood and adulthood resembles the findings of Karin Zetterqvist Nelson (2017b). She argues that the advent of ego psychology in Sweden during the 1970s changed how children were described in the child psychotherapy literature: from being different from adults to being in many ways similar. In the same way, there was no real psychological difference enacted by the psychodynamic mode between the child and the adult: both were equally at risk of being 
affected and controlled by internalized parental images. Moreover, the psychodynamic mode not only enacted the child as fragile and constantly at risk of being disturbed in their development, which seems to have been the emphasis during the 1970s, it also extended this fragility to the adult.

To sum up, the psychodynamic mode of ordering centered on the interaction between parents and child and the effect the former had on the latter's mental health and development. Yet there was a tension in the mode between two figures of the child. On the one hand, the child was enacted as being constituted by the parents' actions and attitudes, as if there was no essence prefiguring their relational configuration. On the other hand, some experts argued that the child had certain given feelings and needs that the parents had to perceive and care for. The mode thus encompassed both an 'empty' child and a 'natural' child. The oscillation between these two could be due to the fact that, while the experts and professionals all agreed upon the importance of taking into account the child's unconscious life and the parents' effect on it, they mobilized slightly different theoretical resources, such as the theories of Margaret Mahler and of Donald Winnicott, to conceptualize and explain the process. These did differ on certain points, leading the articles to suggest slightly differing versions of the child. Yet this should not detract from the overall strong consensus among all the experts that the parents are very important for the child's mental well-being. It is also interesting to note that, compared to earlier forms of psychodynamic theory in Sweden (see Zetterqvist Nelson and Sandin, 2013), the psychodynamic mode seems to have relied more extensively on object relations theory, indicating a shift in the theories that were influential in Sweden during the 1990s compared to the early 1980s.

Additionally, the mode reframed every childhood interaction into a potentially important unconscious event whose true significance only expressed itself in adulthood. This illustrates one key feature of the psychodynamic mode; namely, that it was important to see beyond surface impressions in 
the present. The mode's enactment of child/adult-hood as dimensional and of time as fluid meant that it was never truly certain whether it was the psychological child or the adult who was acting. Apparently destructive and illogical behavior could actually be the expression of an internalized relation from childhood that originally served to protect the child. Mental health issues were thus transformed into signs of childhood neglect, underlining the breakdown of any clear temporal or agentic distinction between the child and the adult.

Finally, I would like to highlight two important aspects of the psychodynamic mode's strong emphasis on the parent-child dyad. First, the mode stressed the individual child as it related the mental health of children to their parents' care-taking and ability to attune to the child's emotional state. In this sense, this article substantiates the findings of previous studies (Zetterqvist Nelson and Sandin, 2013; Zetterqvist Nelson, 2017b) that have shown how psychodynamic theory in Sweden during these decades often coalesced around the individual child. It is even possible to say, I would argue, that the mode not so much individualized children as de-socialized them since they were not really granted any specificity or agency. Instead, the child was assigned a very passive role in relation to the parents (cf. the emergence of the 'competent child' during the later decades of the $20^{\text {th }}$ century, e.g. Brembeck, Johansson and Kampmann, 2004).

Second, the psychodynamic mode's enactment of children's mental health encompassed a quite limited set of entities. In contrast to some earlier forms of psychoanalytic and psychodynamic theory prominent during the 1940s and '50s (Shapira, 2013, 2017; Zetterqvist Nelson and Sandin, 2013), the psychodynamic mode made no connections between children's mental health and questions of a social or political nature. Indeed, the psychodynamic mode's dyad-centered set of entities becomes even 
more intriguing once we contrast it with the contemporaneous neuro-centered mode's emphasis on the important relation between the 'disordered' child and society. It is to this mode that I now turn.

\section{A neuro-centered mode of ordering}

While neuropsychiatric understandings and explanations of adult and child mental illnesses can be traced back to, at least, the late $19^{\text {th }}$ century (Hirschmuller, 1999; Guenther, 2015; Zetterqvist Nelson, 2016), the 'modern' neurosciences that emerged in the 1960 s were characterized by interdisciplinarity - combining fields such as biology, immunology and the behavioral sciences - and a 'neuromolecular gaze' that studied the brain at a molecular level (Abi-Rached and Rose, 2010). Yet they did not have an immediate effect on the child psy sciences. Rather, it was first during the 1980s and '90s that neurocentered child psychiatric and psychological explanatory frameworks and diagnoses, such as ADHD and autism, became globalized and popularized (Smith, 2013; Evans, 2017).

It was also during these decades ${ }^{2}$ that articles started to appear in DN raising the significance of the brain in relation to issues of children's mental health and functioning. These articles contain two quite distinct enactments of the brain. There was both a malleable, dynamic brain, often in the possession of 'normal' children, and a static and differently developed brain that experts and professionals associated with behavioral and emotional problems. This 'atypical' brain was often posited as a fixed backdrop to other aspects of the child, such as behaviors and interactional skills, as these were considered modifiable, in contrast to the 'atypical' brain itself. This difference enacted between the 'normal' and the 'atypical' brain played a significant role in the neuro-centered mode as it led to two distinctive configurations, each of which offered a particular way of ordering and intervening in children's mental health. 
Starting with the 'normal' brain configuration, articles from these decades stated repeatedly that the brain's development was dynamic and affected by its surroundings. For instance, in 1990 a psychiatrist explained that new research had shown how 'the nerve cells aren't fully formed when the person is born' (DN B, 1990, 13 September, p. 14). This meant that the possibility of early influence was 'considerably greater than previously thought.' It was accordingly necessary to revise the notion that the child's brain was unchanging and passive. Instead, it was an organ that was molded by the child's milieu. Similar arguments were espoused in a debate article written in 1986 by David Ingvar, a prolific author and professor of neurophysiology who had authored several books on the brain (e.g. Ingvar, 1976). Ingvar highlighted that the child's early years were crucial since it was then that the 'nerve cells and synapses ... that for the remainder of one's life are going to run the central nervous system' (DN, 1986, 20 August, p. 5) were selected and solidified, while unused ones were pruned away. The purported recent discovery of the brain's dynamic nature and the importance of the child's first years of life raised in articles such as this made a form of neural guidance by parents and other adults possible - and crucial - as it now seemed to be an uncontestable fact that the brain's malleability peaked during early childhood. If parents wanted to affect their child's development, they had therefore better make haste.

Similar to the findings of other social and historical studies on the notion of brain plasticity (e.g. Pickersgill, Martin and Cunningham-Burley, 2015), the enactment of the brain as plastic drew attention to the dynamic interplay between the environment and the brain and generated discussions of the kind of environment that was beneficial for the brain's - and by extension, the child's - health and development. For instance, the significance of providing a cognitively stimulating milieu was discussed, since leaving the child to their own devices could, as a child-psychologist-turned-school-principal put it in an article from the mid-1990s, squander the child's potential. Her school, she explained, was opened in response to the lack of structured instruction in Swedish public schools, particularly the worrying 
absence of pedagogical interventions during the child's third to sixth year, as this was when the brain's capacity to learn peaked. 'Free play,' she asserted, 'does not develop the child, they only do that which they are already good at' (DN, 1994, 5 September, p. 6). For her, childhood was a 'time of intense learning' and not 'an eternally happy fairytale where the child, guided by impulses, runs through a field of flowers.'

The perceived importance of cognitively stimulating the child was certainly not new, as such exhortations can be found in experts' advice to parents from the 1960s onwards (Wrigley, 1989). However, the neuro-centered mode reconfigured this need, and raised the stakes even higher, through relating it to the characteristics and affordances of the child's brain and its developmental trajectory. Now the need to stimulate was not solely justified, as it was during the 1960s, by arguing that the child was an active learner. Rather, it took on a material form embodied in the promise of the brain's timelimited plasticity.

The benefits of stimulating the child, and the disastrous effects of failing to do so, were even more strongly articulated in relation to emotional stimulation. Professor David Ingvar continued his previously mentioned account of 1986 by noting that all humans have the capacity to love and hate but that this had to be "practiced, trained, perfected" (DN, 1986, 20 August, p. 5). Without emotional learning, the child would be unable to express love or tenderness. So, while 'an uneventful, quiet, lonely childhood' could lead to 'bad self-esteem, relational disturbances, life neuroses, isolation, substance abuse,' a childhood 'rich in love, words, melodies, meaningful games, fantasies, and facts creates impressions that make the brain firm and strong in structure.' As this quotation shows, children had to receive both cognitive and emotional support and stimulation to promote optimal and permanent brain 
development. Otherwise, the child would be forever scarred from a lack of proper stimulation and care, leaving a suboptimal brain in its wake.

The enactment of the 'atypical' brain during these three decades - often discernable in articles featuring children who were portrayed as problematic or suffering from psychological or psychiatric illnesses - differed on several points. First, these depictions often used diagnostic labels and categories to describe how, and sometimes to explain why, these children functioned differently, in line with Mats Börjesson's (1999) finding of a large variety of articles in Swedish newspapers during the late 1990s that mentioned neuropsychological and psychiatric diagnoses. While the 'normal' brain was enacted as malleable and responsive, these articles frequently related neuropsychiatric diagnoses to a static 'atypical' brain that lacked the capacity to undergo any significant neurological change. For example, in 2000 a short note summarized how researchers had now concluded that 'some parts of the brain, those that for instance control fine motor skills and working memory, are less developed' (DN, 2000, 25 August, p. 6) in individuals with ADHD and DAMP (Deficits in Attention, Motor Control and Perception). Furthermore, the most significant finding was said to be the discovery of 'an imbalance in the amount of dopamine in the brain of adhd-children [sic].' Although it was argued that medical help could be beneficial, there was no mention of this actually changing the brain itself. It was simply there, as an unchanging fact of nature.

Instead of focusing on affecting the child's brain directly, the articles described how children exhibiting neuropsychological and neuropsychiatric problems could be helped by behavioral techniques. For example, during the early 2000s, there were articles describing the therapeutic Son-Rise program, in which the parents of children with autism used imitation techniques to stimulate 'contact and interaction, on the child's terms' (DN B, 2002, 14 September, p. 20), and the attempts by professionals 
to help children diagnosed with ADHD and similar problems to 'verbalize what they are feeling' and learn how to handle their anger as an alternative to 'throwing a chair' (DN Stockholm, 2004, 20 September, p. 6). Neither article mentioned affecting the brain directly; interventions relevant to these 'atypical' brains instead targeted a behavioral level, without reference to any form of neurological change.

Besides individualized treatment, this configuration also highlighted society and its role in exacerbating children's problems and discussed what society needed to do to help children with neurologically varying functioning. For example, one expert who argued for the need to rearrange children's school environment was Björn Kadesjö, a chief school physician who later on became part of Christopher Gillberg's influential yet quite controversial research group on neuropsychiatric disorders (see Gornall, 2007, for a summary of the controversies surrounding Gillberg; and Evans, 2017, for details on Gillberg's contributions to research on autism). Kadesjö remarked that 'the preschool's environment and way of working ... influence the preschool children's ability to concentrate' to a very high degree and that 'the unconcentrated children get to constantly feel that ... they are difficult' (DN, 1986, 31 August, p. 5). Children's varying ability to concentrate could be due to many factors, according to Kadesjö, including biological disabilities. He nevertheless thought that the situation was leading to a 'new inequality: between those who have the ability to benefit from modern society and those for whom it is destructive.'

It is worth noting that this critique was not solely expressed by individuals trained in the medical and psychological sciences. Criticism similar to Kadesjö's was voiced in the late 1990 s by the father of a child with autism. He expressed amazement that 'prejudices surrounding handicapped people are still alive' and that there was such a lack of 'knowledge and compassion among decision-makers within the health 
care, welfare services and school sectors' (DN C, 1998, 3 September, p. 5). The unique needs of children with autism, as well as the demands and wishes of their parents, were, he argued, being disregarded by the authorities. The perceived clash between the wants and needs of children with 'atypical' brains and the ignorance of society and the authorities returned in several other articles during the late 1990s and mid-2000s as well (e.g. DN B, 1998, 4 September, p. 18; DN, 2006, 26 August, p. 34). These underscore how the neuro-centered mode of ordering stressed the importance for the child's mental well-being of a beneficial relation between the 'atypical' child and his brain and society. Several factors contributing to the clash were outlined in these articles, such as economic and cultural changes in contemporary society as well as ignorant and reluctant authorities and experts. The overall message was that there was a current mismatch between how these children, and their brains, functioned and the society in which they lived. Society was thus attributed a large share of the responsibility for these children's mental health; meanwhile, parents mostly figured in these articles as tirelessly struggling against uncaring bureaucrats and experts.

The discussions in the articles regarding 'atypical' children and their relation to society have parallels with those outlined by Bonnie Evans (2017) in her historical study of the emergence of the modern concept of autism. She argues that the notion of children's rights, including the right to an education, was an important factor in early autism research and activism in Britain. Influential autism researchers, such as Lorna Wing, were strong proponents of including children with autism spectrum disorders in society, instead of placing them in separate institutions, and the new theories of autism that were articulated during the 1970 s and ' 80 s helped to justify such an inclusive approach to children in general, regardless of their level of functioning. While the explicit notion of children's rights cannot be said to have played an equally important role in the articles analyzed here, such an inclusionary approach can 
still be seen to underlie many of the discussions taking place during these decades as it was argued that society needed to adapt to the children, instead of vice versa.

The emphasis on social recognition and assistance highlights the significance of - and difference between - the two parallel configurations of the neuro-centered mode. The 'normal' brain was enacted as a malleable entity that developed continuously in interaction with its surroundings, particularly by being stimulated cognitively and emotionally by parents and other important adults. Meanwhile the 'atypical' - and often diagnosed - brain was enacted as more or less static and lacking the ability to be molded into a 'better-working' brain. Instead its limitations had to be compensated for and its strengths supported. Here, society, prejudiced and ignorant, came to the fore while the parents were mostly described as struggling to acquire proper assistance for their children. The two configurations thus each designated a specific trajectory for children's mental health and encompassed a particular way of ordering it, while still revolving around the notion that knowledge of the brain and its workings was of fundamental importance.

It is further interesting to note that there were no mentions of pharmacological treatments in these articles, especially considering how harshly the neuropsychiatric framework has been criticized for only promoting medical treatments that entail a reductionist and discriminatory view of children (e.g. Kärfve, 2000; Timimi, 2010). In broad strokes, the argument goes that neuropsychiatric classifications and explanations of children's health and development lead to decontextualized and individualized solutions that obscure the real - i.e. often political and social - causes of children's problems and mental illhealth. While there were a few articles and chronicles published during the 1990s that brought up the issue of psychopharmacological medication, these were written by lay people and often took a very disapproving and ironic tone in criticizing the 'utopian' hope that they thought was often placed in 
pharmacological solutions (e.g. DN B, 1990, 20 August, p. 2; DN C, 1996, 24 August, p. 5). As mentioned, the articles featuring experts and professionals often focused instead on intervening at a behavioral level or reorganizing society and its institutions so as to better fit the 'atypical' children.

I would argue that these findings encourage both recognition of the diversity and heterogeneity of the neuro-centered sciences and reflection upon whether they necessarily entail many of the oppressive and reductionist consequences of which they have been accused. These constellations of knowledges and practices are not - at least not to the extent often assumed - ignorant of the importance of political, social and economic contexts and factors (Fitzgerald, 2017) and there may be 'no straightforward story about the impact of neuroscience on subjectivity' (Ortega and Choudhury, 2011, p. 336). Instead, it is a matter of a rather wide range of epistemologies, aims, methods and investigatory techniques that can have diverse implications for children's mental health depending on how they are configured and mobilized. This can be seen in DN during these years as there is a general lack of references to, or arguments drawing upon, psychopharmacological research. Instead, the articles mention technologies such as PET scans (DN B, 1990, 13 September, p. 14) and stress the behavioral aspects of the problems exhibited by children with neuropsychiatric disorders (DN B, 1998, 4 September, p. 18). This particular way of assembling the neuro-centered mode thus led to an emphasis on the social dimensions and repercussions of such illnesses - illustrating that the neurosciences may be configured in more complex ways than some critics have acknowledged. This may be particularly important as the neurosciences have arguably only increased in influence since 2008 and their techniques and explanations have been mobilized in many diverse areas of life, making nuanced descriptions and understandings of them even more vital. 
Lastly, the neuro-centered mode often temporalized psychological diagnoses and disorders. A common claim was that earlier misconceptions of mental illnesses had now been dispelled; for instance, '[the] myth that all mental illnesses have a psychological and social explanation' (DN, 1988, 19 September, p. 22). Children with ADHD had always existed, according to a 2008 article summarizing a television show, and you could find ADHD in all cultures and social classes (DN Kultur, 2008, 4 September, p. 18). This held for autism as well, as it was not caused by poor attachment between mother and child but by a biological disability (DN, 2006, 26 August, p. 26). Believed to surpass the misguided explanations of disorders and illnesses championed in previous times, the neuro-centered ordering mode claimed to uncover an absolute biological and neurological dysfunction that was centered in the atemporal disordered brain. Hence the neuro-centered mode decoupled the etiologybut, importantly, not the treatment - of many mental health issues from society.

\section{Overlapping and diverging orderings: A concluding discussion}

In this article, I have drawn on Actor-Network Theory (ANT) and the concept of modes of ordering (Law, 1994) to analyze two modes of ordering children's mental health that are discernable in the Swedish morning paper Dagens Nyheter: a psychodynamic and a neuro-centered mode. These two modes were to a large extent contemporaneous, with the psychodynamic mode being present during the 1980 s and 1990s and the neuro-centered mode during the 1980s up until 2008. While both were prominent during these relatively overlapping years, they differed significantly in how they enacted children's mental health, particularly concerning which distinctive entity needed to be taken into account if one was to understand children's psychological well-being: the unconscious and the brain, respectively. To give a better overview of these two modes and their interrelationship, I will focus my discussion on how they ordered the child, the family and the importance of childhood for understanding mental ill-health. 
Regarding the figure of the child, the psychodynamic mode enacted a fairly homogeneous figure of the child, with every child having similar needs and attributes, and instead stressed that it was the child's parental environment that affected her mental health. The mentally healthy child was therefore constitutionally similar to the mentally ill, with any differences between them attributable to the parents' caretaking. The neuro-centered mode, in contrast, enacted a difference between the child with a 'normal' brain and the child with an 'atypical' brain, each with its own abilities and limitations. Here, children could differ constitutionally, and this difference then explained why some children suffered illhealth.

The family was performed as a significant entity to consider in both modes, yet each had its own rendition of exactly how it was important. The psychodynamic mode presented the parents, or often even solely the mother, as the only entity that mattered for children's mental health. Meanwhile, the neuro-centered mode's two configurations each had its own ordering of the family. In some ways similar to the psychodynamic mode, the 'normal brain' configuration enacted the family as a vital environment that had to provide enough cognitive and emotional stimulation for the child, whereas the 'atypical brain' mostly figured the family's task as ensuring that the child received adequate help from society.

Interestingly, both modes stressed the importance of childhood for understanding adult mental issues by highlighting how experiencing childhood neglect or having an 'atypical' brain, respectively, could lead to future problems. Grasping the nature of childhood was thus vital in both modes as it was enacted as being inseparably connected with adults' psychological well-being.

Nevertheless, while there were overlaps between the two modes, their general implications for the presumptive reader differed greatly, particularly if we consider which assemblage of entities each mode stressed as being important for mental health issues. Tracing the psychodynamic mode's enactment of 
children's mental health takes us to the parents and their effect on the structure and functioning of the child's unconscious. Hence, the only significant factor to take into account was the interaction between parents and child and its effect on the latter's mental health. Any questions about children's mental health were therefore answered by consistently referring to the parents and their impact on the child and nothing else. The psychodynamic mode thus presented an ordering that was dominated by a very clearly defined set of human actors.

In contrast, the neuro-centered mode encompassed a more heterogeneous set of entities that included parents, biological objects and processes as well as notions of society and its institutions. While its two configurations both emphasized the importance of the brain, they each incorporated a slightly different set of entities. The 'normal' brain configuration stressed the parents' effect on the child's cognitive and emotional development, while the 'atypical' brain configuration highlighted behaviorally focused treatments as well as support from society. The neuro-centered mode could thus offer several different answers to questions about children's mental well-being and development.

This clearly highlights how these two relatively contemporaneous modes represented two very different ways of ordering children's mental health. But there was even more at stake as they also offered to enroll readers into specific versions of the socio-natural context in general, including how society was organized. This latter aspect is especially prominent in the neuro-centered mode as it discussed society and its relation to children's mental health to a greater extent. The two modes could thus have significant consequences for children and their lives as they offered very different explanations of children's mental well-being and provided diverging reference points for parents, experts and institutions. 
The historical ANT narrative offered in this article differs in some ways from a 'traditional' historical narrative. I have not primarily written a contextual narrative into which I introduce already settled contexts and categories from, say, economics, political science or cultural theory and analyze how the modes' composition can be explained by transformations in the Swedish welfare system (Swärd, 2017), the economic crisis of the early 1990s (Bergmark and Palme, 2003) or new political ideologies and governing strategies (Dahlstedt, Fejes and Schönning, 2011). Instead of positioning a given society as the primary, yet invisible, explanans of these modes (see Latour, 2003, 2005), I wanted to conduct an indepth exploration of how they themselves enacted a specific socio-natural world in which they embedded the issue of children's mental health. This meant that I focused not on what made the experts' and professionals' statements possible but rather on what these circulating statements themselves made possible (Asdal, 2012) in terms of how, say, a parent reading the morning paper may come to think of their child's mental health but also of society in general.

This approach may be particularly relevant for cases such as this, where we have two relatively contemporaneous modes offering different versions of children's psychological health. I have wanted to avoid claiming that, despite their differences, they were part of the same context, e.g. Swedish society with its history, politics and economic structures, and that it is primarily through such terms that they should be explained and understood. The ANT narrative offered in this article instead highlights how the modes also enacted their own social and natural context and that the differences between these had important consequences for how each mode enacted children's mental health.

To conclude, I have shown how the relatively contemporaneous psychodynamic and neuro-centered modes entailed starkly different ways of enacting children's mental health. The psychodynamic mode highlighted the child's unconscious as the central entity to consider and related all issues of mental ill- 
health to the parents' care-taking. The neuro-centered mode enacted a difference between the child with a 'normal' brain and the child with an 'atypical' brain. The 'normal' brain was plastic and dynamic and its development relied on the parents stimulating it cognitively and emotionally. The 'atypical' brain was presented as static, unchangeable and, quite often, also as diagnosed and had to primarily receive expert help, in the form of behavioral interventions, as well as recognition and support from social institutions and the authorities. Thus, each mode of ordering enacted not only particular versions of the child's mental health but also of the surrounding social and material context, highlighting how issues of childhood are often bound up with questions about the social (and, I would argue, the natural) order (James, Jenks and Prout, 1998).

By using ANT as my theoretical and analytical framework, I have explored and illustrated an alternative approach to studying the history of the psy sciences. This has entailed in particular a skepticism toward imposing already settled contexts and ontologies on my material. The risk, I would argue (see also Asdal, 2012; Law \& Moser, 2012; Ward, 2002), is that an analytically given context, if we may call it that, which is too strong overpowers the content and the context enacted by psy experts themselves, obscuring important aspects that can provide analytical purchase and help to clarify the effects of, and differences between, different strands of the psy sciences. Thus, ANT's stress on empirical detail and ontological agnosticism can, in this manner, open up space for exploring alternative ways of conceptualizing and writing the history of the psy sciences.

\section{References}

Abi-Rached, J. M. and Rose, N. (2010) 'The Birth of the Neuromolecular Gaze', History of the Human Sciences, 23(1): 11-36.

Asdal, K. (2012) 'Contexts in Action--And the Future of the Past in STS', Science, Technology \& Human 
Values, 37(4): 379-403.

Asdal, K. (2015) 'What Is the Issue? The Transformative Capacity of Documents', Distinktion: Scandinavian Journal of Social Theory, 16(1): 74-90.

Ash, M. G. (2003) 'Psychology', in T. M. Porter and D. Ross (eds) The Cambridge History of Science, Volume 7: The Modern Social Sciences. Cambridge: Cambridge University Press, pp. 251-274.

Axelsson, T. (2009) 'Någonstans mellan sjukt och friskt. Det Psykopatiska Barnet och Psykopatklasser' [Somewhere Between III and Healthy. The Psychopathic Child and Psychopath Classes], in J. Lind, C. Lindgren, M. Sjöberg and K. Zetterqvist Nelson (eds) Historien, Barnen och Barndomarna - Vad Är Problemet? [The History, the Children and the Childhoods - What Is the Problem?]. Linköping: Linköping Universitet, pp. 27-50.

Bergenheim, Å. (1997) 'Skå-Gustav och Barnpsykiatrin' [Skå-Gustav and the Child Psychiatry], in B.E. Eriksson and R. Qvarsell (eds) Hur Skall Själen Läkas? [How Should the Soul Be Healed?]. Stockholm: Natur och Kultur, pp. 183-214.

Bergenheim, Å. (2013) Varm choklad och Psykoterapi: Om Ericastiftelsen i Stockholm [Hot Chocolate and Psychoterapy: On the Erica Foundation in Stockholm]. Stockholm: Carlsson Bokförlag.

Bergmark, Å. and Palme, J. (2003) 'Welfare and the Unemployment Crisis: Sweden in the 1990s', International Journal of Social Welfare, 12: 108-122.

Bommenel, E. (2006) Sockerförsöket : Kariesexperiment 1943-1960 på Vipeholms Sjukhus För Sinnesslöa [The Sugar Trial: Caries Experiment 1943-1960 at Vipeholm's Hospital For Feebleminded]. Lund: Arkiv Förlag. 
Börjesson, M. (1999) 'A Newspaper Campaign Tells: The Launch of Neuro-psychiatric Diagnoses in the Swedish Daily Press 1997-1999', Scandinavian Journal of Disability Research, 1(2): 3-25.

Börjesson, M. and Palmblad, E. (eds) (2003) Problembarnets Århundrade - Normalitet, Expertis och Visionen om Framsteg [The Century of the Problem Child - Normality, Expertise and the Vision of Progress]. Lund: Studentlitteratur.

Brembeck, H., Johansson, B. and Kampmann, J. (eds) (2004) Beyond the Competent Child: Exploring Contemporary Childhoods in the Nordic Welfare Societies. Frederiksberg: Roskile University Press.

Callon, M. (1986) 'Some Elements of a Sociology of Translation: Domestication of the Scallops and the Fishermen of St Brieuc Bay', in J. Law (ed.) Power, Action and Belief: A New Sociology of Knowledge? London: Routledge, pp. 196-223.

Clarke, J. N. (2011) 'Childhood Depression and Mass Print Magazines in the USA and Canada: 19832008', Child and Family Social Work, 16(1): 52-60.

Clarke, J. N. (2013) 'Medicalisation and Changes in Advice to Mothers About Children's Mental Health Issues 1970 to 1990 as Compared to 1991 to 2010: Evidence from Chatelaine Magazine.', Health, Risk \& Society, 15(5): 416-431.

Dagens Nyheter (2008) Om Dagens Nyheter [About Dagens Nyheter]. Available at: https://www.dn.se/nyheter/om-dagens-nyheter/ (Accessed: 20 October 2017). Dagens Nyheter (2018) Statistik för Dagens Nyheter [Statistics for Dagens Nyheter]. Available at: https://annons.dn.se/sv-se/stats (Accessed: 3 May 2018).

Dahlstedt, M., Fejes, A. and Schönning, E. (2011) 'The Will to (De)Liberate: Shaping Governable Citizens 
Through Cognitive Behavioural Programmes in School', Journal of Education Policy, 26(3): 399-414.

Evans, B. (2017) The Metamorphosis of Autism. Manchester: Manchester University Press.

Felski, R. (2011) “'Context Stinks!”', New Literary History, 42(4): 573-591.

Felski, R. (2015) The Limits of Critique. Chicago: The University of Chicago Press.

Fitzgerald, D. (2017) Tracing Autism: Uncertainty, Ambiguity and the Affective Labor of Neuroscience. Seattle: University of Washington Press.

Gleason, M. (1996) ‘Disciplining Children, Disciplining Parents: The Nature and Meaning of Advice to Canadian Parents, 1945-1955', Histoire Sociale/Social History, 29(57): 187-209.

Gornall, J. (2007) 'Hyperactivity in Children: The Gillberg Affair', BMJ, 335(7616): 370-373.

Guenther, K. (2015) Localization and Its Discontents: A Genealogy of Psychoanalysis and the Neuro Disciplines. Chicago: University of Chicago Press.

Hess, V. and Majerus, B. (2011) 'Writing the History of Psychiatry in the 20th century', History of Psychiatry, 22(2): 139-145.

Hirschmuller, A. (1999) 'The Development of Psychiatry and Neurology in the Nineteenth Century', History of Psychiatry, 10(40): 395-423.

Ingvar, D. H. (1976) Rapport Från Hjärnan: Om Medvetande, Minne, Sömn och Drömmar [Report From the Brain: On Conciousness, Memory, Sleep and Dreams]. Stockholm: Bonnier.

James, A., Jenks, C. and Prout, A. (1998) Theorizing Childhood. London: Polity Press.

Jones, E. (2012) 'Neuro Psychiatry 1943: The Role of Documentary Film in the Dissemination of Medical 
Knowledge and Promotion of the UK Psychiatric Profession', Journal of the History of Medicine and Allied Sciences, 69(2): 1-31.

Jönson, U. (1997) Bråkiga, Lösaktiga och Nagelbitande Barn: Om Barn och Barnproblem Vid en Rådgivningsbyrå i Stockholm 1933-1950 [Restless, Dissolute and Nailbiting Children: On Children and Child Problems at an Advice Bureau in Stockholm 1933-1950] (Doctoral Dissertation). Linköping: Linköping University.

Kärfve, E. (2000) Hjärnspöken : DAMP och Hotet Mot Folkhälsan [Brain Ghosts: DAMP and the Threat to Public Health]. Eslöv: Symposion.

Latour, B. (1996) 'On Actor-Network Theory: A Few Clarifications Plus More Than a Few Complications', Soziale Welt, 47: 369-381.

Latour, B. (1999) Pandora's Hope: Essays on the Reality of Science Studies. Cambridge: Harvard University Press.

Latour, B. (2003) 'The Promises of Constructivism', in D. Ihde (ed.) Chasing Technology: Matrix of Materiality. Bloomington: Indiana University Press, pp. 27-46.

Latour, B. (2005) Reassembling the Social: An Introduction to Actor-Network-Theory. Oxford: Oxford University Press.

Law, J. (1994) Organizing Modernity: Social Ordering and Social Theory. Oxford: Wiley.

Law, J. (2008a) 'Actor-Network Theory and Material Semiotics', in B.S. Turner (ed.) The New Blackwell Companion to Social Theory. Oxford: Blackwell, pp. 141-158.

Law, J. (2008b) 'On Sociology and STS', Sociological Review, 56(4): 623-649. 
Law, J., Afdal, G., Asdal, K., Lin, W., Moser, I. and Singleton, V. (2014) 'Modes of Syncretism: Notes on Noncoherence', Common Knowledge, 20(1): 172-192.

Law, J. and Moser, I. (2012) 'Contexts and Culling', Science, Technology \& Human Values, 37(4): 332354.

Littmarck, S. (2017) Barn, Föräldrar, Välfärdsstat: Den Politiska Debatten om Föräldrautbildning och Föräldrastöd 1964-2009 [Children, Parents, Welfare State: The Political Debate About Parent Education and Parenting Support 1964-2009] (Doctoral Dissertation). Linköping: Linköping University.

McDougall, J. (1985) Theaters of the Mind : Illusion and Truth on the Psychoanalytic Stage. New York: Basic Books.

Mitchell, S. A. and Black, M. J. (1995) Freud and Beyond: A History of Modern Psychoanalytic Thought. New York: Basic Books.

Mol, A. (1999) 'Ontological Politics: A Word and Some Questions', The Sociological Review, 47(S1): 7489.

Mol, A. (2002) The Body Multiple: Ontology in Medical Practice. Durham: Duke University Press.

Ohlsson, A. (2008) Myt och Manipulation: Radikal Psykiatrikritik i Svensk Offentlig Idédebatt 1968-1973 [Myth and Manipulation: Radical Critique of Psychiatry in Swedish Public Debate of Ideas 1968-1973] (Doctoral Dissertation). Stockholm: Acta Universitatis Stockholmiensis.

Olofsson, A. (2002) Waves of Controversy: Gene Technology in Dagens Nyheter 1973-96 (Doctoral Dissertation). Umeå: Umeå University.

Ortega, F. and Choudhury, S. (2011) "'Wired Up Differently": Autism, Adolescence and the Politics of 
Neurological Identities', Subjectivity, 4(3): 323-345.

Peter Wolodarski (2017) DN Ökade Antalet Prenumeranter Under 2016, Dagens Nyheter [DN Increased In the Number of Subscribers During 2016]. Available at: https://www.dn.se/nyheter/sverige/dn-okadeantalet-prenumeranter-under-2016/ (Accessed: 20 October 2017).

Pickersgill, M., Martin, P. and Cunningham-Burley, S. (2015) 'The Changing Brain: Neuroscience and the Enduring Import of Everyday Experience', Public Understanding of Science, 24(7): 1-16.

Qvarsell, R. (1985) 'Från Vanart till Psykopati' [From Naughtiness to Psychopathy], Lychnos, pp. 167-189.

Qvarsell, R. (1991) Vårdens idéhistoria [The History of Ideas of the Health Care]. Stockholm: Carlsson Bokförlag.

Qvarsell, R. (1993) '“Brustna sinnen"' [Broken Minds], in Skall jag taga vara på min broder? [Shall I Take Care of My Brother?]. Umeå: Umeå University, pp. 83-97.

Rigné, E. M. (2002) Profession, Science and State-Psychology in Sweden 1968-1990 (Doctoral Dissertation). Göteborg: Göteborgs Universitet.

Rose, N. (1996) Inventing Our Selves: Psychology, Power, and Personhood. Cambridge: Cambridge University Press.

Rose, N. (1999) Governing the Soul: The Shaping of the Private Self. London: Free Association Books.

Rose, N. (2007) ‘Beyond medicalisation’, The Lancet, 369(9562): 700-702.

Sandin, B. and Halldén, G. (2003) 'Välfärdsstatens Omvandling och En Ny Barndom' [The Transformations of the Welfare State and a New Childhood], in B. Sandin and G. Halldén (eds) Barnets Bästa - En Antologi om Barndomens Innebörder och Välfärdens Organisering [The Best of the Child - An 
Anthology on the Meanings of Childhood and the Organisation of the Welfare]. Stockholm: Symposion, pp. 7-23.

Scull, A. (2015) 'Contending Professions: Sciences of the Brain and Mind in the United States, 18502013', Science in Context, 28(01): 131-161.

Shapira, M. (2013) The War Inside: Psychoanalysis, Total War, and the Making of the Democratic Self in Postwar Britain. Cambridge: Cambridge University Press.

Shapira, M. (2017) “" Speaking Kleinian ”: Susan Isaacs as Ursula Wise and the Inter-war Popularisation of Psychoanalysis', Medical History, 61(4): 525-547.

Shogimen, T. (2016) 'On the Elusiveness of Context', History and Theory, 55(2): 233-252.

Skagius, P. and Münger, A.-C. (2016) 'Professional Reinventions: Swedish Psychologists, 1990 - 2010', History of Psychology, 19(4): 274-297.

Smith, M. (2013) Hyperactive: The Controversial History of ADHD. London: Reaktion Books.

Söderlind, I. and Engwall, K. (2005) Var Kommer Barnen In? - Barn i Politik, Vetenskap och Dagspress.[Where Do the Children Come In? - Children in Politics, Science and the Daily Press] Stockholm: Institutet för Framtidsstudier.

Swärd, H. (ed.) (2017) Den Kantstötta Välfärden [The Chipped Welfare]. Lund: Studentlitteratur.

Teo, T. (2005) The Critique of Psychology: From Kant to Postcolonial Theory. New York: Springer Science \& Business Media.

Thomson, M. (2006) Psychological Subjects: Identity, Culture, and Health in Twentieth-Century Britain. Oxford: Oxford University Press. 
Timimi, S. (2010) 'The McDonaldization of Childhood: Children's Mental health in Neo-Liberal Market Cultures', Transcultural Psychiatry, 47(5): 686-706.

Vicedo, M. (2011) 'The Social Nature of the Mother's Tie to Her Child: John Bowlby's Theory of Attachment in Post-War America', The British Journal for the History of Science, 44(03): 401-426.

Vicedo, M. (2013) The Nature \& Nurture of Love: From Imprinting to Attachment in Cold War America. Chicago: The University of Chicago Press.

Ward, S. (1996) 'Filling the World With Self-esteem: A Social History of Truth-making', Canadian Journal of Sociology, 21(1): 1-23.

Ward, S. (2002) Modernizing the Mind: Psychological Knowledge and the Remaking of Society. Westport: Praeger.

Wright, K. (2008) 'Theorizing Therapeutic Culture: Past Influences, Future Directions', Journal of Sociology, 44(4): 321-336.

Wrigley, J. (1989) ‘Do Young Children Need Intellectual Stimulation? Experts' Advice to Parents, 19001985', History of Education Quarterly, 29(1): 41-75.

Zetterqvist Nelson, K. (2009) ‘När Bowlby Kom till Sverige. Från Motstånd till Erkännande: Anknytningsteori i Sverige 1950-2000' [When Bowlby Came to Sweden. From Resistance to Recognition], in A-M. Markström, M. Simonsson, I. Söderlind and E. Änggård (eds) Barn, Barndom och Föräldraskap [Children, Childhood and Parenthood]. Stockholm: Carlsson Bokförlag, pp. 271-289.

Zetterqvist Nelson, K. (2011) 'The Sandtray Technique for Swedish Children 1945-1960: Diagnostics, Psychotherapy and Processes of Individualisation', Paedagogica Historica, 47(6): 825-840. 
Zetterqvist Nelson, K. (2016) “"A Reason Behind Every Action”: The Early Years of Swedish Child Psychiatry 1930-1945', Revue d'Histoire de l'Enfance " Irrégulière », 18: 201-211.

Zetterqvist Nelson, K. (2017a) ‘En Udda Fågel På Besök : John Bowlby och Den Svenska Efterkrigstidens Barnpsykiatriska Expertis' [An Odd Bird On Visit: John Bowlby and the Swedish Postwar Child Psychiatric Experts], Socialvetenskaplig tidskrift, 24(1): 1-18.

Zetterqvist Nelson, K. (2017b) 'The Changing Construction of the Child Figure in Literature on Child Psychotherapy in Sweden 1945-1975', in J. Albeck, P. Lappalainen and K. Launis (eds.) Childhood, Literature and Science. Fragile Subjects. London: Routledge, pp. 68-79.

Zetterqvist Nelson, K. and Sandin, B. (2013) 'Psychodynamics in Child Psychiatry in Sweden, 1945-85: From Political Vision to Treatment Ideology', History of Psychiatry, 24(3): 308-325.

\section{Notes}

${ }^{1}$ Twenty articles published between 1984 and 2004 formed part of the analysis, the majority from the period 1986 to 1996.

${ }^{2}$ The analysis of the neuro-centered mode is based on 22 articles published between 1982 and 2008, with most articles being published from 1986 onwards. 